\title{
PHYTOREMEDIATION AND METAL UPTAKE IN FOOD PLANTS
}

\author{
Maria Greger \\ Clara Neuschütz \\ Tommy Landberg \\ Agneta Göthberg \\ Johanna Nyqvist \\ Beata Dabrowska \\ Stockholm University, Stockholm, Sweden
}

\begin{abstract}
This paper reviews some of our resent findings on metal uptake in phytotechnology and food plants. The Cd concentration in wheat grains can be decreased by pytoextraction by Salix prior to wheat cultivation. Water spinach commonly grown in nutrient rich waste water are able to form methyl-Hg in new leaves, but high nutrient level in cultivation medium decreases the metal concentration in the plant. Wetland plants grown on mine tailings are able to decrease the formation of acid mine drainage from the tailings. Submerged plants can increase the retention of metals in wetlands treating metal polluted water, but the efficiency depends on the quality of the inlet water. Plants can be used to prevent leakage of metals and nutrients from dry covers containing sewage sludge on mine tailing impoundments. If the sealing layer below the cover layer consists of fly ash root penetration can be prevented while if it contains a mixture of sewage sludge and fly ash roots will grow into the sealing layer. Macro algae as fertilizers in agriculture increase the biomass production but also transfer $\mathrm{Cd}$ to the crop. Therefore, algae should be used in production of non food crops, however, not suitable for hemp cultivation.
\end{abstract}

\section{KEYWORDS}

Cadmium, fly ash, heavy metals, hemp, macroalgal fertilizers, methyl-Hg, mine tailings, phytoextraction, phytofiltration, Salix, sewage sludge, submerged plants, water spinach, wetland plants, wheat.

\section{INTRODUCTION}

Plants take up and accumulate metals and can therefore be used in various environmental treatment processes. However, the uptake can also be a problem in cultivation of food crop. This paper deals with research on these topics produced by the Plant metal Group at the Department of Botany, Stockholm University.

\section{LOW Cd CONTENT IN WHEAT GRAINS BY PHYTOEXTRACTION WITH SALIX}

In Sweden, the Cd concentrations in agricultural soil are in some areas elevated due to antropogenic pollution or the $\mathrm{Cd}$ concentration in the bedrock. This is a problem for the 
cultivation of wheat since wheat accumulates $\mathrm{Cd}$ in their grains and wheat flour products stand for $43 \%$ of the total $\mathrm{Cd}$ intake via food in humans (8). Prior to wheat cultivation, remediation of metal-contaminated soils, so-called phytoextraction, using non-food crops such as Salix can be a tool to decrease the Cd content in soil and thereby in grains with subsequent decrease in human $\mathrm{Cd}$ intake.

Some Salix clones used in bioenergy production have high uptake of $\mathrm{Cd}$ and is shown to be able to remove $\mathrm{Cd}$ from soil by $\mathrm{Cd}$ uptake (5). Removal of $\mathrm{Cd}$ from soil by Salix viminalis was also shown at a field site in Fliseryd, south-east part of Sweden in the vicinity of a former battery factory. Different numbers $(0-25)$ of cuttings were planted per square meter in May 1997. Soil samples were collected both before plantation (1997) and after three years of cultivation (2000). The total $\mathrm{Cd}$ concentration $\left(\mathrm{HNO}_{3}\right.$-extraction) decreased up to $32 \%$ within three years by Salix cultivation and the higher plant density the more Cd was removed (Table 1).

The Cd accumulation in grains of wheat cultivated in soil after 1.5 years of Salix cultivation is investigated. This investigation is performed in a field at Brunnby farm in the vicinity of Västerås, in Sweden and is still ongoing. Salix viminalis was planted at high and low density, 9 and 25 plants per square meter, respectively, in May 2005 and was removed September 2006. Thereafter, winter wheat was sown on the plots where Salix had been removed and also on plots where no Salix had been grown. The Cd content in grains decreased if the soil had been phytoextracted with Salix (Figure 1).

Table 1. Cadmium concentration in soil before and after three years cultivation of Salix viminalis planted with various plant densities ending up in various plant biomass (ton $\mathrm{ha}^{-1}$ ). *Significant difference from the start data. Indicated is metal removal in percent. [6]

\begin{tabular}{cccc}
\hline Year & $\begin{array}{c}\text { Stem } \\
\text { biomass, } \\
\text { tonnes } \\
\text { ha }^{-1}\end{array}$ & $\begin{array}{c}{[\mathrm{Cd}]_{(1 \mathrm{NO})} \text { in }} \\
\text { soil, } \mathrm{mg} \mathrm{kg}^{-1}\end{array}$ & $\begin{array}{c}\text { Cd } \\
\text { removal, } \\
\%\end{array}$ \\
\hline 1997 & 0 & 1.10 & - \\
2000 & 0 & 1.12 & - \\
2000 & 2 & $1.05^{*}$ & 5 \\
2000 & 19 & $0.85^{*}$ & 23 \\
2000 & 48 & $0.75^{*}$ & 32 \\
\hline
\end{tabular}




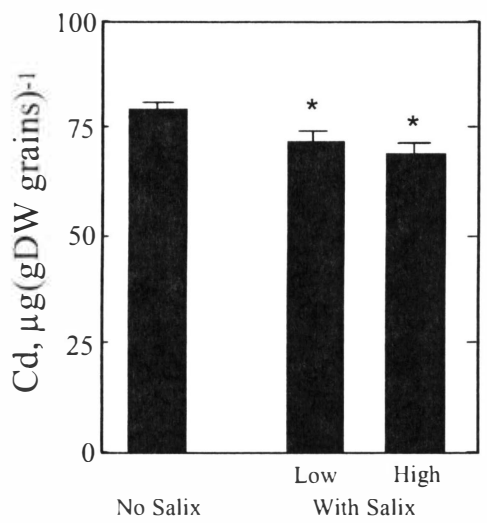

Figure 1. Cadmium in grains from wheat cultivated in soil without pregrow'th with Salix (no Salix) and after 1.5 years of cultivation of Salix viminalis (with Salix). Salix were cultivated with two different densities. ne $4 \pm S E$. *significant different.

\section{CULtivating THE ASIAN VEGETABle, WATER SPINACH IN WASTE WATER}

Water spinach (Ipomoea aquatica) is a popular vegetable in Southeast Asia, cultivated in freshwater courses. These often serve as recipients for waste waters that often contain pollutants such as heavy metals. The plant grows with the old stems and roots in the water while the shoots grow above the water surface. The young shoots are collected as food. This plant accumulates heavy metals. In an investigation on the metal content in water spinach collected from several sites in the Bangkok area in Thailand $\mathrm{Pb}, \mathrm{Cd}$ and $\mathrm{Hg}$ was found and the levels of $\mathrm{Hg}$ were high in plants from some sites (2). Although the $\mathrm{Pb}$ and $\mathrm{Cd}$ concentrations in the plants do not may to be a direct threat to human health according to threshold values for highest tolerable intake by humans the methyl-Hg levels seem to be a problem. The methyl$\mathrm{Hg}$ could be formed externally by bacteria and be taken up into the plant but it was also shown that this plant was able to form methyl-Hg by itself in young shoots (Figure 2,4).

High nutrient levels, often occurring in waste waters, decreased the uptake of metals in this plant (3), also that of methyl-Hg (Figure 3). Present studies also show that the formation of methyl-Hg is influenced by the nutrient level. Another reason for lower concentration of metals in plants in the presence of high nutrient level may be a dilution effect by the increased growth of the plant. It seems that if waste waters contains high nutrient levels the risk of high metal concentration in the plants diminish. 


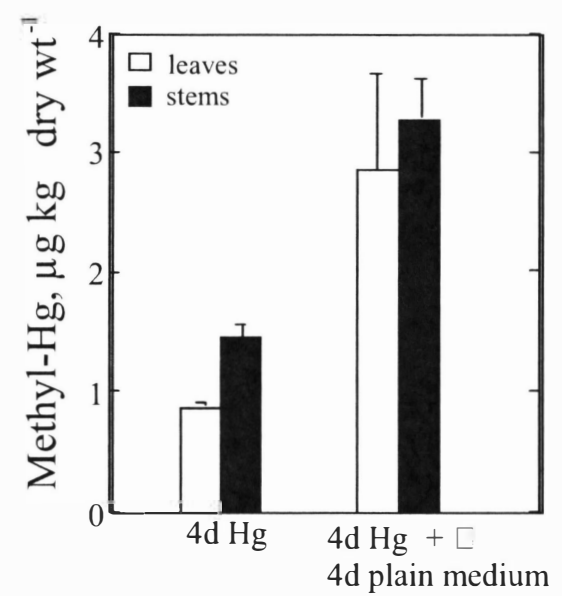

Figure 2. Concentrations of methyl- $\mathrm{Hg}$ in leaves and stems of young shoots after $4 d$ of exposure to $0.2 \mu \mathrm{M} \mathrm{HgCl} 2 \pm$ additional four days in plain nutrient medium. $n=3 \pm S E$ (from 4)

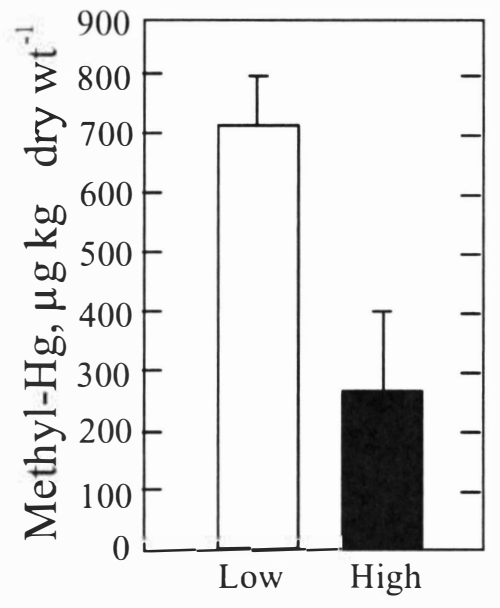

Figure 3. Methyl-Hg in young shoots of water spinach after 4 days of growth in low $(7.5 \%)$ and high $(75 \%)$ concentration of the nutrient medium Hoagland and $0.02 \mu \mathrm{M}$ methyl-Hg. $n=3 \pm S E$.

\section{MINE TAILING TREATMENTS FROM METALS USING WETLAND PLANTS}

Waste from mines causes major environmental problems due to high metal concentration. Mine tailings is fine grained sand, which is waste produced from mining and is stored in tailing impoundments. Many ores that are rich in metals consist of pyrite $\left(\mathrm{FeS}_{2}\right)$ and other sulphide-rich minerals. Oxidation of these minerals in mine tailing generates protons, metals and As forming acid mine drainage (AMD). To avoid the oxygen penetration either wet-cover or dry cover is used. The wet cover consists of a high water table (1.5-2 $\mathrm{m})$ over the tailings to reduce wave erosion and resuspension of the tailings. However, the high water table require high impoundment walls that are expensive to build and also the pressure from the water might reduce the stability of the walls, which makes a threat since the walls can break.

Recent data shows that the water table can be lowered to a couple of $\mathrm{cm}$ and along with plantation of wetland plants the formation of AMD can be decreased. This is due to that the wetland plants prevent $\mathrm{pH}$ decrease in the tailings, which in turn decrease the release of metals from the tailings (Table 2,13). The likely reason for this increase in $\mathrm{pH}$ is that high free metal concentration in the tailings triggers the plants to increase the $\mathrm{pH}$ to avoid further high free metals in the surrounding. The data shows that it is possible to create wetlands on top of the mine tailings impoundments and thereby decrease the formation of AMD. This has been further studied with similar results in a pilot wetland in the field at Kristineberg mine site. 
Table 2. Metal and sulphate concentrations and $\mathrm{pH}$ in leakage water from mine tailings not treated or treated with sewage sludge (SS) alone or with common cotton grass (Eriophorum angustifolium). $N=6 \pm S E$. (from 13).

\begin{tabular}{lcccccc}
\hline Treatment & $\mathrm{Cd}, \underline{\mu \mathrm{gL}^{-1}}$ & $\mathrm{~Pb}, \underline{\mu \mathrm{gL}^{-1}}$ & $\mathrm{Cu}, \underline{\mathrm{mgL}^{-1}}$ & $\mathrm{Zn}, \underline{\mathrm{mgL}^{-1}}$ & $\underline{\mathrm{pH}}$ & $\mathrm{SO}_{4}^{-2}, \mathrm{mgL}^{-1}$ \\
\cline { 1 - 4 } Control & $435 \pm 50$ & $8134 \pm 253$ & $3.21 \pm 0.37$ & $123 \pm 14$ & $2.61 \pm 0.01$ & $1137 \pm 47$ \\
+ SS & $29 \pm 8$ & $5864 \pm 1431$ & $0.30 \pm 0.11$ & $5 \pm 1$ & $2.75 \pm 0.32$ & $394 \pm 32$ \\
+ SS+Plants & $7 \pm 1$ & $92 \pm 24$ & $0.04 \pm 0.02$ & $6 \pm 1$ & $5.85 \pm 0.18$ & $608 \pm 37$ \\
\hline
\end{tabular}

\section{PHYTOFILTRATION OF ACID MINE DRAINAGE AND STORMWATER}

Acid mine drainage is formed due to weathering of mine tailings; it is acidic (down to $\mathrm{pH} 2.3$ ) and contains high levels of metals, especially iron. Stormwater comprises of rainwater and meltwater draining from hard surfaces such as roofs and roads in urban areas. It often contains elevated levels of $\mathrm{Cu}, \mathrm{Zn}, \mathrm{Cd}$ and $\mathrm{Pb}$ but the $\mathrm{pH}$ is more neutral than that of AMD.

Submerged plants, such as Elodea canadensis and Potamogeton natans is shown to accumulate high concentrations of metals in stormwater-treatment wetlands (1). Plants can still take up metals even though the plants already contain high metal levels (12). Submerged plants are therefore possible tools in removal of metals from water such as stormwater and AMD. It is shown that wetlands with plants are more efficient to retain metals in the wetland and by that ending up with a more clean effluent water (Table 3). This is due to both the metal uptake but also that plants retard the water flow increasing the sedimentation of particles. The removal of metals is more efficient from storm water than from AMD (Table 3). This is likely due to the higher metal concentration in the water of AMD, but also to the lower pH of AMD causing an interaction between metal ions and hydrogen ions at the uptake sites (9). Another reason is that Fe-plack is precipitated all over the whole plant body, which at to high level can cause death of the plants by preventing photosynthetic activity.

Table 3. Metal retention from stormwater-like water and AMD-like water in laboratory scale wetlands. ne 5-28.

\begin{tabular}{lllll}
\hline Water & & \multicolumn{2}{l}{ Metal retention, \% } & $\mathrm{Cd}$ \\
\cline { 2 - 4 } & Treatment & $\mathrm{Zn}$ & $\mathrm{Cu}$ & \\
\hline Storm-water & & & $24 \pm 8$ \\
& unplanted & $63 \pm 3$ & $67 \pm 3$ & $50 \pm 5$ \\
& E.canadensis & $74 \pm 2$ & $79 \pm 2$ & $40 \pm 4$ \\
\multirow{2}{*}{ AMD } & P. natans & $70 \pm 3$ & $81 \pm 2$ & $29 \pm 8$ \\
& & & & $37 \pm 11$ \\
\hline
\end{tabular}

\section{ROLES OF PLANTS IN DRY COVERS OF FLY ASH AND SEWAGE SLUDGE}

Formation of acid mine drainage (AMD) from sulphidic mine tailings can be prevented by a dry cover consisting of fly ash (FA) and sewage sludge (SS) that protects the tailings from reacting with oxygen and water. The FAs often have alkaline and pozzolanic properties, 
making them suitable as sealing layer components, while SS may be used together with the FA in the sealing layer or as a protective cover, supporting establishment of vegetation. The question is how plants will affect the function and durability of the cover.

Establishment of vegetation is important to prevent erosion of the dry cover, as well as of aesthetical reasons. However, the conditions in newly applied SS may cause problems for plants to form roots. Both field trials and greenhouse pot experiments have shown that the ability to establish in pure SS differ between plant species, and that plants that are introduced as seeds have a higher ability to survive to the next growth season, compared with trees and herbs that are transferred as whole plants (10). Addition of sand $(33 \% \mathrm{v}: \mathrm{v})$ increased the germination rate of seeds and root formation of willow cuttings, as well as decreased the activity of stress related enzymes (peroxidases) in needles of Norway spruce. Therefore, addition of sand can be a method to improve the establishment of plants in SS.

Sewage sludge contains large amounts of nitrogen and phosphorus, and sometimes high levels of metals, which may leach out to surrounding water and cause eutrophication and metal pollution. Plants growing in the SS can have a strong preventive effect on the release of elements, primarily by decreasing the amount of formed drainage water. The ability to prevent leakage from SS differs, however, widely between plant species. In a greenhouse study it was found that fast growing plants (Epilobium angustifolium L., Phalaris arundinacea L., and Salix viminalis L.) decreased the amounts of leakage water (with up to $50 \%$ ), suspended solids (up to $75 \%$ ) and the concentrations of ammonium and phosphate (up to $77 \%$ and $54 \%$ respectively) when being cultivated in SS for 10 weeks. Nitrate and Cd concentrations were also decreased by the grass (with $16 \%$ and $27 \%$, respectively), while $S$. viminalis decreased $\mathrm{Cu}$ concentrations with $30 \%$, but increased nitrate concentrations with $63 \%$. Pinus sylvestris L. did not have any preventive effect on leakage of any of the measured parameters. Thus, to prevent leakage of nutrients and metals from newly applied SS, introduction of a quick growing grass is recommended.

A sealing layer has to stay intact to prevent diffusion of oxygen down to the mine tailings. Therefore it is important that roots from plants growing in the overlying cover do not penetrate the sealing layer. Since there is a risk of crack formation in sealing layers only consisting of FA, it has been suggested that SS should be added to increase the plasticity. However, addition of SS also means addition of nutrients, and lowering of $\mathrm{pH}$ and mechanical resistance, which results in improved growth conditions for plants, and a subsequent increased risk of root penetration. This has also been shown in greenhouse studies, both with nutrient poor moraine (11) or nutritious SS on top of sealing layers of FA or mixtures of FA and SS. In the latter experiment $P$. arundinacea was grown for 1 year in containers with sealing layers either consisting of only FA, or FA mixed with SS (60:40 w:w). At the time of harvest the plant roots had succeeded in penetrating the $8 \mathrm{~cm}$ thick sealing layer when SS was added, while the FA layer only allowed roots in the upper $\mathrm{cm}$ (Table 4). The bulk density of the sealing layer with only FA was $1140 \mathrm{~kg} \mathrm{~m}^{-3}$, compared to $490 \mathrm{~kg} \mathrm{~m}^{-3}$ in the FA/SS mixture. The same was found in a field study where $P$. arundinacea had been growing for three years in $30 \mathrm{~cm}$ deep SS on top of $80 \mathrm{~cm}$ deep sealing layers of either only FA or FA/SS (70:30 v:v). In this case roots were found at depths of $5 \mathrm{~cm}$ in the FA-layer and at $25 \mathrm{~cm}$ in the FA/SS layer. 
Table 4. Root growth and $\mathrm{pH}$ after 1 year of cultivation in a dry cover consisting of sewage sludge on top of a sealing layer with either 100\% fly ash (FA) or $60 \%$ fly ash and 40\% sewage sludge (FA:SS). ne $4 \pm S E$

\begin{tabular}{|c|c|c|c|c|c|c|c|c|}
\hline \multirow[t]{2}{*}{ Layer } & \multicolumn{4}{|c|}{ Root biomass ( $\left.\mathrm{mg} \mathrm{cm}^{-3} \mathrm{DW}\right)$} & \multicolumn{4}{|c|}{$\mathrm{pH}$} \\
\hline & \multicolumn{2}{|c|}{ FA } & \multicolumn{2}{|c|}{ FA:SS } & \multicolumn{2}{|c|}{ FA } & \multicolumn{2}{|c|}{ FA:SS } \\
\hline \multicolumn{9}{|c|}{ Cover of sewage sludge } \\
\hline Upper $3 \mathrm{~cm}$ & 32.6 & \pm 7.5 & 32.9 & \pm 6.9 & 5.4 & \pm 0.2 & 5.2 & \pm 0.2 \\
\hline Lower $3 \mathrm{~cm}$ & 4.3 & \pm 1.1 & 3.4 & \pm 0.6 & 5.6 & \pm 0.2 & 5.9 & \pm 0.2 \\
\hline \multicolumn{9}{|l|}{ Sealing layer } \\
\hline Upper $3 \mathrm{~cm}$ & 6.9 & \pm 2.3 & 13.0 & \pm 5.0 & 8.4 & \pm 0.1 & 7.2 & \pm 0.1 \\
\hline Lower $3 \mathrm{~cm}$ & 0 & & 1.2 & \pm 0.8 & 8.6 & \pm 0.3 & 7.8 & \pm 0.2 \\
\hline Mine tailings & 0 & & 0.3 & \pm 0.2 & 2.8 & \pm 0.1 & 4.8 & \pm 0.4 \\
\hline
\end{tabular}

\section{ALGAE AS FERTILIZERS IN CULTIVATION OF FOOD AND ENERGY CROP}

Eutrophication of the Baltic Sea has led to an increase in the growth of filamentous red and brown macro algae. In late summer and autumn, large quantities of these algae accumulates along the coast and ends up in beach cast along the coasts of the island Öland among others. Beach casts of macro algae has earlier been used as fertilizers in agriculture and horticulture and both red and brown algal compost is shown to increase the biomass of crop (Figure 4). However, since algae accumulates heavy metals from the water a question arouse that the metals could be transferred from the algae via soil to the cultivated plants. In a resent work we showed that among the analysed metals only cadmium increased in the crop plants in the presence of composted algae (7). The algal composts contained elevated level of $\mathrm{Cd}$ and transferred $\mathrm{Cd}$ to the edible parts of the crop plants (Figure 4).

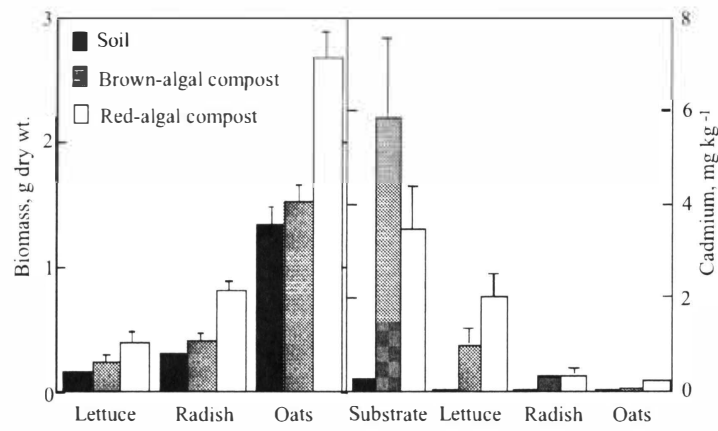

Figure 4. Biomass (left) and Cd concentration (right) of edible parts of crop plants and Cd concentration in substrate (soil and composts of brown and red algae, respectively) in which the plants have grown. The algal composts were mixed with $20 \%$ of oat straw before use (from 7).

Of this reason it was discussed to cultivate energy crop in algal fertilized soil instead of food crops. Also the bioenergy crop could remove the $\mathrm{Cd}$ from the soil. Therefore, the growth and 
Cd uptake of hemp (Cannabis sativa) and willow (Salix viminalis) during the summer season 2005 was investigated at a field site, Torslunda field station, at the island Öland. Soil had been fertilized with fresh beach cast to use less concentration of algae $(0,1$ and $3 \%)$ than in the previous study $(20-50 \%)$, in which the algal mat was composted prior to use. Hemp seed did not germinate well in the presence of fresh beach cast. Therefore, the number of hemp plants per square meter was lower in the presence than in the absence of beach cast. Plants grow up to a maximum height of 4 meter. On the other hand, Salix performed well in algal fertilized soil and grow from cuttings to 2.5 meter height during the summer season. Hemp took up $\mathrm{Cd}$ and the higher up in the plant the higher were the $\mathrm{Cd}$ concentration, with highest concentration in the leaves (Figure 5). However, the Cd concentrations in stem of hemp only reach half of that in Salix. The concentration of $\mathrm{Cd}$ in hemp was slight higher in plants in the presence than in the absence of beach-cast fertilized soil (Figure 5).

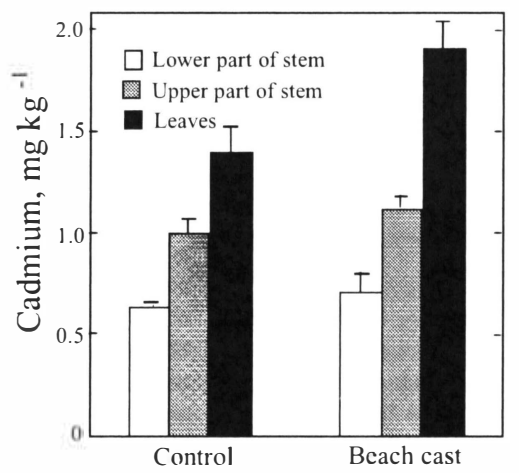

Figure 5. Cadmium concentration in hemp cultivated in the absence or in the presence of $1 \%$ beach cast. $n=4 \pm S E$.

\section{REFERENCES}

[1] Fritioff, $\AA$., Greger, M., 2003. Aquatic and terrestrial plant species with potential to remove heavy metals from stormwater. International Journal of Phytoremediation 5, 211-224.

[2] Göthberg, A., Greger, M., Bengtsson, B.-E., 2002. Accumulation of heavy metals in water spinach (Ipomea aquatica) cultivated in the Bankok region, Thailand. Environmental Toxicology and Chemistry 21, 1934-1939.

[3] Göthberg, A., Greger, M., Holm, K., Bengtsson, B.-E., 2004. Influence of nutrient levels on uptake and effects of mercury, cadmium, and lead in water spinach. Journal of Environmental Quality 33, 1247-1255.

[4] Göthberg, A., Greger, M., 2006. Formation of methyl mercury in an aquatic macrophyte. Chemosphere 65, 2095-2105.

[5] Greger, M., Landberg, T., 1999. Use of willow in phytoextraction. International Journal of Phytoremediation 1, 115-124.

[6] Greger, M., Landberg, T., 2003. Improving removal of metals from soil by Salix. In: Proceedings of $7^{\text {th }}$. Int. Conf. on the Biogeochemistry of trace elements, June 15-19, 2003, Uppsala, Sweden, pp. 146-147. 
[7] Greger, M., Malm, T., Kautsky, L., 2007. Heavy metal transfer from composted macroalgae to crops. European Journal of Agronomy 26, 257-265.

[8] Hellstrand, S., Lander, L., 1998. Cadmium in fertilizers, soil, crops and foods - the Swedish situation. Ine Cadmium exposure in the Swedish environment. Kemi report no $1 / 98$.

[9] Marschner, H., 1995. Mineral nutrition of higher plants. Academic Press.

[10] Neuschütz, C., Stoltz, E., Greger, M., 2005. Choice of vegetation for treatment of mine tailings covered with fly ashes and sewage sludge. Proceedings of Securing the Future, International Conference on Mining and the Environment - Metals and Energy Recovery. June 27 - July 1, 2005, Skellefteå, Sweden, pp. 779-786.

[11] Neuschütz, C., Stoltz, E., Greger, M., 2006. Root penetration of sealing layers made of fly ash and sewage sludge. Journal of Environmental Quality 35, 1260-1268.

[12] Nyquist, J., Greger, M., 2007. Uptake of $\mathrm{Zn}, \mathrm{Cu}$, and $\mathrm{Cd}$ in metal loaded Elodea canadensis. Environmental and Experimental Botany 60, 219-226.

[13] Stoltz, E., Greger, M., 2002. Cottongrass effects on trace elements in submersed mine tailings. Journal of Environmental Quality 31, 1477-1483 